\title{
Systemic analysis of the health sector through the input-output matrix, 2000-2005
}

\author{
Fernando Salgueiro Perobelli, Mônica Viegas Andrade, Edson \\ Paulo Domingues, Flaviane Sousa Santiago, Joilson de Assis \\ Cabral and Lucas Barbosa Rodrigues
}

ABSTRACT

This article provides a systemic analysis of the health sector in Brazil, based on a study of its productive structure and its interactions with the other sectors of the economy. The article draws on unpublished data on the National Health Accounts provided by the Brazilian Geographical and Statistical Institute (IBGE); and it proposes a methodology for harmonizing the System of National Accounts (input-output matrix) with the Health Satellite Accounts for 2000 and 2005. This sheds light on the relations that exist between the health sector and the other sectors the economy, through input-output indicators.

KEYWORDS

JEL CLASSIFICATION

AUTHORS
Health, health services, input-output analysis, health economics, national accounts, macroeconomics, productivity, Brazil

I10, D57

Fernando Salgueiro Perobelli is an associate professor at the Federal University of Juiz de Fora, Brazil. fernando.perobelli@uff.edu.br

Mônica Viegas Andrade is an associate professor at the Federal University of Minas Gerais, Brazil. mviegas@cedeplar.ufmg.br

Edson Paulo Domingues is an associate professor at the Federal University of Minas Gerais, Brazil. domingues.edson@gmail.com

Flaviane Sousa Santiago is a research assistant at the Federal University of Minas Gerais, Brazil. santiago. flaviane@gmail.com

Joilson de Assis Cabral is an assistant professor at the Rural Federal University of Rio de Janeiro, Brazil. cabraljoilson@gmail.com

Lucas Barbosa Rodrigues is an economics teacher at the Federal University of Juiz de Fora, Brazil. Lucasbr_rodrigues@hotmail.com 


\section{I}

\section{Introduction}

The health sector has major effects on the level of social welfare. From the individual standpoint, the consumption of the goods and services produced by this sector affects well-being directly, since an individual's health status determines the degree to which he/she feels completely well. From the macroeconomic perspective, the health sector affects economic growth, since it forms part of the stock of human capital and determines the economy's productive capacity (WHO, 2001; Bloom, Canning and Sevilla, 2001). Over the last few years, health spending in both developed and developing economies has grown considerably in per capita terms (by $3 \%$ per year on average in the countries of the Organization for Economic Cooperation and Development (OECD) (OECD, 2010)). This increase is largely explained by the introduction of new technologies and changes in the population's epidemiological profile, since a higher prevalence of chronic diseases results in more intensive use of hospital services. In Brazil, public and private health expenditure jointly account for roughly $8 \%$ of gross domestic product (GDP) — similar to the $8.9 \%$ average among OECD countries in 2009-. In absolute terms, health expenditure in Brazil was equivalent to US\$ 674 per capita at 2006 purchasing power parity (WHO, 2009), compared to a global per capita average of US\$ 790. In sector-dynamic terms, health expenditure in Brazil has maintained a broadly constant share of GDP over the last few years (IBGE, 2008). This relative stability partly reflects budgetary control by the government, which restrains public expenditure. In economies with health systems that are predominantly public, tighter control of health expenditure is normal.

Aside from the health sector's importance in terms of GDP share, other characteristics provide insights into its dynamism and sectoral interaction in the economy at large. The delivery of health care, particularly in the case of low- and medium-complexity services, is a labour-intensive productive process that absorbs a large proportion of the employed population. Most

The authors are grateful for the funding received to carry out this work from the Foundation for Coordinating the Improvement of Staff in Higher Education (CAPES), within the framework of the National Programme for Academic Cooperation (PROCAD) of the National Council for Scientific and Technological Development (CNPq). of the services in question cannot be provided on a commercial basis and respond to demand in the area of residence. In contrast, high-complexity health-sector activities, particularly diagnostic services and drug manufacturing, are technology-intensive. Consequently, those health subsectors are more interdependent with the external sector, either directly, for example through equipment purchase, or indirectly, through inputs to perform medical procedures. Technological-intensity varies between countries and seems to be related to the ways the services in question are financed and delivered in each country.

This article makes a systemic analysis of the health sector in Brazil, by studying its productive structure and interactions with the other sectors of the economy. It draws on unpublished data on the National Health Accounts, provided by the Brazilian Geographical and Statistical Institute (IBGE), and it puts forward a methodology for harmonizing the System of National Accounts (input-output matrix) with the Health Satellite Accounts for 2000 and 2005. ${ }^{1}$ That harmonization helps to clarify the relations that exist between health and other sectors of the economy, and makes it possible to measure the effects of health policies on the macroeconomic aggregates using input-output indicators. The National Health Accounts System adopted in Brazil follows the international accounts model, which enables comparisons to be made between countries.

Input-output matrices are a suitable tool for analysing interdependence between the different sectors in an economy. Their main function is to make it possible to evaluate a sector's production requirements to satisfy a given sectoral structure of final demand for goods and services. The input-output methodology has been used for analysis in different areas; and in Brazil there are applications relating to most of the industrial sectors -agriculture (Rodrigues and Guilhoto, 2004), transport (Toyoshima and Ferreira, 2002; Betarelli Junior, Bastos and Perobelli, 2008), income distribution (Azzoni and others, 2007; Moreira, 2007), energy (Perobelli, Mattos and Faria, 2007; Mattos and others, 2008) and

\footnotetext{
1 This article uses the tables of resources and uses for the health subsectors and the tables of uses of goods and services for those subsectors.
} 
environmental issues (Hilgemberg and Guilhoto, 2006; Imori and Guilhoto, 2007), among others. Nonetheless, studies focusing specifically on the health sector are scarce. Most international research on this sector, using the input-output methodology, focuses mainly on intra-sectoral relations (Correa and Parker, 2005; Hongyi, 2009).

This study contributes to the input-output literature in Brazil and helps fill the gap in specific analyses of the health sector. With the epidemiological transition and population ageing processes that are unfolding in Brazil, health expenditure is likely to increase in the future; and this could have differentiated effects on the economy, according to the relations that exist between the health sector and other economic sectors. In that connection, the harmonization of the Brazilian input-output matrix is an important tool allowing for a higher level of health sector disaggregation. Moreover, gaining a better understanding of inter-sectoral relations is fundamental for optimizing the planning of public health policies, in the context of consolidating and expanding the Brazilian health system, particularly its public-sector component.

The rest of this article is structured as follows: section II discusses the Brazilian health sector, and section III describes the harmonization of the National Health Accounts with the System of National Accounts. Section IV reviews descriptive statistics of the inputoutput matrix expanded to include subsectors of the health sector, while section $\mathrm{V}$ analyzes the other health subsectors based on the input-output model. Lastly, section VI concludes.

\section{II}

\section{The health sector in Brazil}

This section describes the performance of the Brazilian health sector based on an extensive sample of OECD countries, including a number of Latin American ones. Three indicators are used: health sector expenditure as a proportion of GDP, life expectancy at birth, and health expenditure measured in purchasing-power-parity terms. Life expectancy at birth is generally used in the literature as an indicator of the population's average health status, since it takes account of all age groups and all surviving cohorts (Robine, Romieu and Cambois, 1999; Almeida and others, 2000; Andrade, 2002; Camargo, Rodrigues and Machado, 2006; Terra and Queiroz, 2010). Although this indicator has a number of limitations, since it does not include the morbidity dimension or quality of life at the individual level, it is the best measure, particularly for making international comparisons. Indicators of expenditure as a proportion of GDP and expenditure at purchasing power parity are mutually complementary. The first relates to the allocation of health expenditure in the countries in question, while the second provides a measure of the level of expenditure per person. Two countries can allocate health spending in the same way, but at very different levels according to per capita income differences.

Figure 1 shows the relation between the proportion of GDP spent on health and GDP per capita in 2007. The shape of the curve reveals a monotonic relation between health expenditure and per capita GDP, because the wealthier countries allocate a larger share of their GDP to the health sector. Although Brazil's per capita GDP is low (US\$ 7,185 at purchasing power parity), it is located on the curve, suggesting that the allocation of expenditure to the health sector in terms of relative share of output follows the same pattern as seen in the developed countries. It is interesting to note Brazil's situation compared with that of other Latin American countries: while Mexico and Chile both have very similar per capita GDPs to Brazil's, they spend a much smaller share of GDP on health. Moreover, while GDP levels in Argentina and Cuba are below that of Brazil, their relative share of health expenditure is very similar to that seen in developed countries. Among the latter, the United States records the highest level of expenditure, close to $16 \%$ of GDP, and occupies a position well above the fitted curve of health expenditure against per capita GDP. Other developed countries, such as Germany (10.4\%), Canada (10.1\%) and France (11\%) fit the curve well.

Figure 2 shows the relation between life expectancy at birth and per capita GDP. Life expectancy is a measure of economic welfare. The curve has a quadratic shape which suggests a positive relation but with life expectancy increasing at declining rates as per capita GDP grows. In other words, it suggests a concave health production function, which makes clear that health gains are greater 
FIGURE 1

Share of GDP spent on health and per capita GDP, selected countries 2007 (US dollars at purchasing power parity)

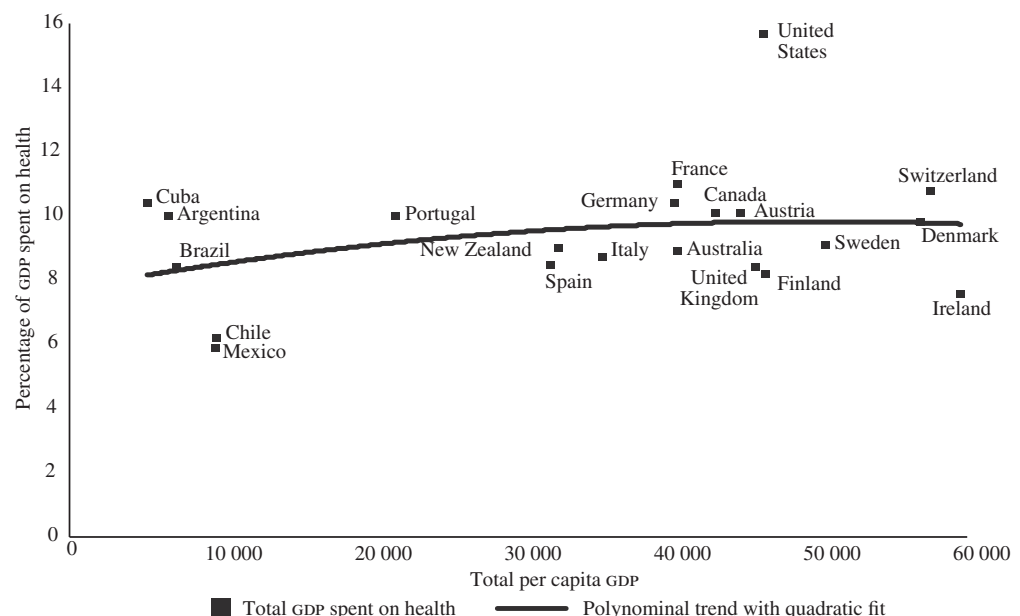

Source: World Health Organization (wHO), "Global health indicators", World Health Statistics 2010, Geneva, 2010 [online] http://www.who. int/whosis/whostat/EN_WHS10_Full.pdf?ua=1; World Bank, "GDP per capita", 2007 [online] http://data.worldbank.org/indicator/NY.GDP. PCAP.CD?order=wbapi_data_value_2007+wbapi_data_value\&sort=asc.

FIGURE 2

Life expectancy at birth and per capita GDP, selected countries 2007

(Years and US dollars)

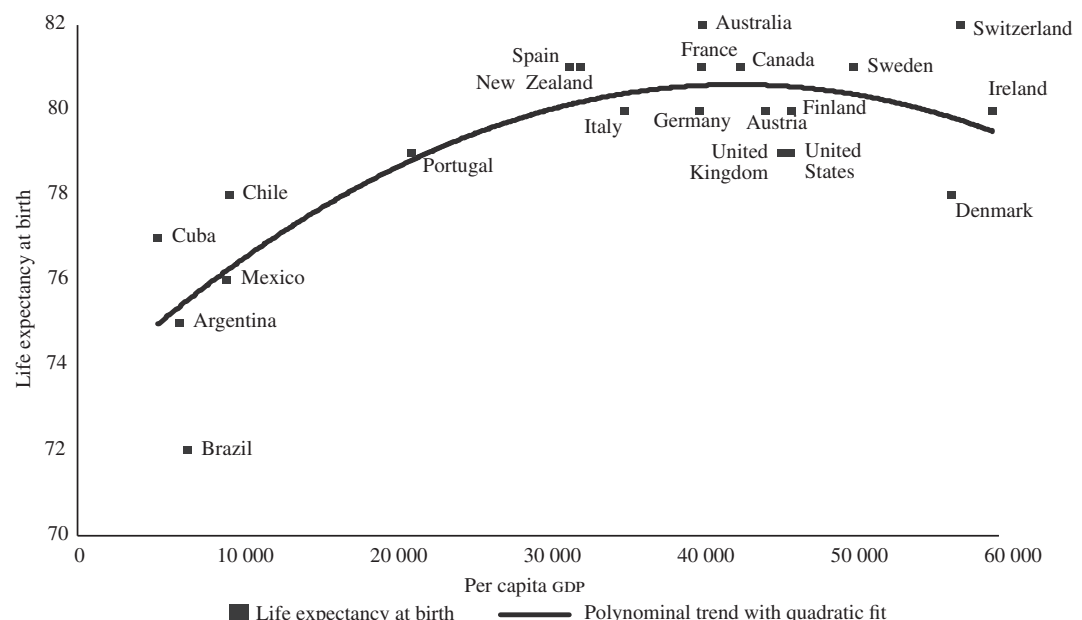

Source: World Health Organization (wHO), "Global health indicators", World Health Statistics 2010, Geneva, 2010 [online] http://www.who. int/whosis/whostat/EN_WHS10_Full.pdf?ua=1; World Bank, “GDP per capita”, 2007 [online] http://data.worldbank.org/indicator/NY.GDP. PCAP.CD?order=wbapi_data_value_2007+wbapi_data_value\&sort=asc.

among the poorer countries. As the economy's wealth grows, the health gains for individuals are ever smaller, bearing in mind the life-cycle dimension (mortality). Brazil's location on the graph is well below the fitted curve, which suggests that Brazilian life expectancy is well below what would be expected in terms of the country's wealth. It also probably reflects the high level of child mortality in Brazil (close to 20 per 1,000 live births compared to the figures in developed countries, where rates are generally below 10 per 1,000 live births). According to the health economics literature, the Brazilian epidemiological profile reveals infectious/contagious diseases typical of less developed countries, coexisting with the chronic-degenerative diseases that are typical 
of developed countries (Luna, 2002; Schramm and others, 2004; Brazil, Ministry of Health, 2004 and 2010; Campelo, Gonçalves and Donadi, 2005).

Lastly, figure 3 corroborates the results of the previous figure, by analysing life expectancy in relation to total health expenditure calculated at purchasing power parity. The shape of the curve is the same as that obtained previously, thereby reinforcing the notion of a concave health-care production function. The relation in question makes it possible to rank countries in terms of technical efficiency, because the curve shows the life expectancy that would be predicted by the level of health expenditure. Brazil's low position on the graph reveals a degree of expenditure inefficiency (Marinho, Cardoso and Almeida, 2009; Ribeiro and Rodrigues Jr., 2006; Ribeiro, 2008). The authors of the present article believe this reflects the persistence of health problems that are typical of poorer countries, stemming above all from a lack of sanitation and basic public health services for certain segments of the population.

The indicators presented show Brazil's relative position with respect to global health indicators and expenditure. To gain a better understanding of that position, the following sections analyse the structural characteristics of the health sector and how it integrates into the productive system.

FIGURE 3

Life expectancy at birth and per capita health expenditure, selected countries 2007 (Years and US dollars at purchasing power parity)

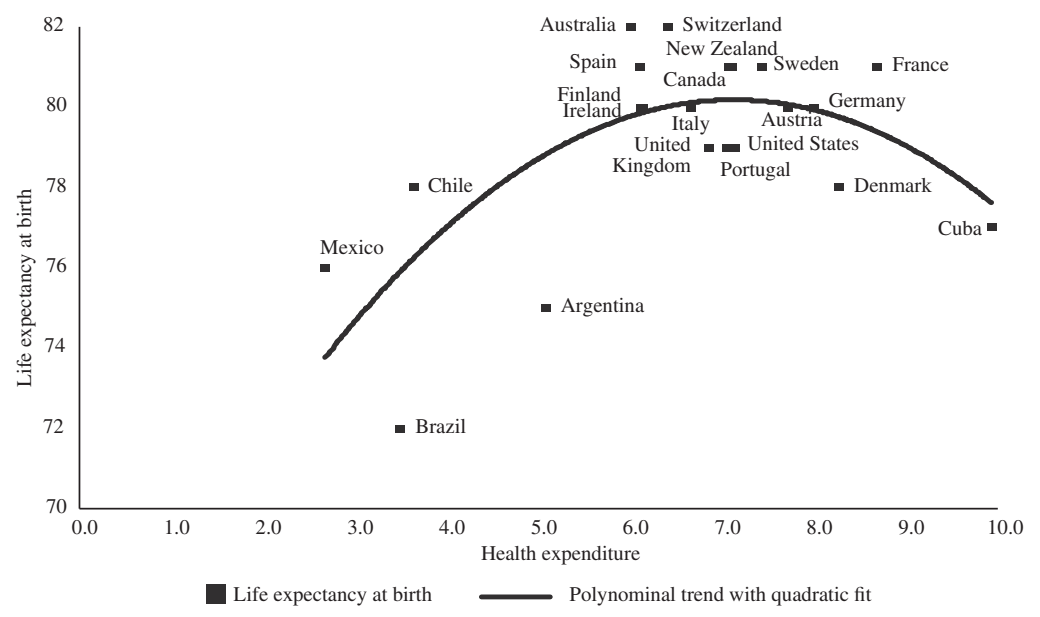

Source: World Health Organization (wHO), "Global health indicators", World Health Statistics 2010, Geneva, 2010 [online] http://www.who. int/whosis/whostat/EN_WHS10_Full.pdf?ua=1; World Bank, "GDP per capita”, 2007 [online] http://data.worldbank.org/indicator/NY.GDP. PCAP.CD?order=wbapi_data_value_2007+wbapi_data_value\&sort=asc.

\section{III}

\section{Harmonization of the National Health Accounts with the System of National Accounts}

This section describes the procedure used to harmonize Brazil's input-output matrices with the aim of incorporating the breakdown of the economic activities of the health sector in 2000 and 2005. Two data systems were used: (i) the System of National Accounts of the IBGE (2000 and 2005), which divides the Brazilian input-output matrix into 55 sectors, and (ii) the National Health Accounts System, also published by the IBGE, which reports five economic activities of the health sector in addition to those already existing. The new version of the input-output matrix proposed in this study thus comprises 60 sectors - the 55 original ones together 
with the five health subsectors. As the structure of the input-output matrices is similar for all available years, the same procedure is adopted.

Tables 1 and 2 show the breakdown according to the technology of the activity and product in the System of National Accounts (original breakdown), and the respective breakdown in the National Health Accounts System. The first column shows the subsector or original output of the System of National Accounts; and the second shows the classification available in the National Health Accounts System proposed by the IBGE. As can be seen, four subsectors and seven additional health-related products were created.

Three key tables were used from the System of National Accounts: the table of resources of goods and services, which shows their supply in the economy at current prices, and import values; the table of uses of goods and services at consumer prices, which provides the economy's value added; and the table of supply of and demand for production at basic prices, which specifies the values of intermediate consumption and final demand. The three tables originally encompass 110 products and 55 sectors, forming a 110x 55 matrix.

From the National Health Accounts System, data on the total value of output was obtained from the resources of goods and services table; and these were combined with data on intermediate consumption and value added obtained from the uses of goods and services table.

Application of the input-output methodology requires the technology type (sector or product) under which the matrix will be constructed to be defined. This article chose an input-output model with sector-based technology, so that the final matrix is a 60x60 square matrix constructed from the market-share matrix. The procedures adopted in the harmonization are described in more depth in annex I.

TABLE 1

\section{Description of the health subsectors in the System of National Accounts and National Health Accounts}

\begin{tabular}{ll}
\hline Health subsector & Other health subsectors \\
\hline $\begin{array}{l}\text { Pharmaceutical products } \\
\text { Manufacture of apparatus for } \\
\text { medical-hospital and dental use }\end{array}$ & $\begin{array}{l}\text { Manufacture of pharmaceutical products } \\
\text { Manufacture of apparatus for medical-hospital and dental use }\end{array}$ \\
Commerce & $\begin{array}{l}\text { Other commerce } \\
\text { Trade in pharmaceutical, medical, orthopaedic and dental products }\end{array}$ \\
Financial intermediation and insurance & $\begin{array}{l}\text { Financial intermediation and other insurance } \\
\text { Complementary medical care }\end{array}$ \\
Corporate health care & $\begin{array}{l}\text { Hospital care activities } \\
\text { Other health-care-related activities } \\
\text { Private social services }\end{array}$ \\
\end{tabular}

Source: Brazilian Geographical and Statistical Institute (IBGE), Sistema de Contas Nacionais and Contas Nacionais em Saúde, 2005.

TABLE 2

Original product and breakdown of products in the System of National Accounts

\begin{tabular}{ll}
\hline Health product & Health subproducts \\
\hline Pharmaceutical products & $\begin{array}{l}\text { Pharmaco-chemical products } \\
\text { Medicines for human use } \\
\text { Medicines for veterinary use } \\
\text { Materials for medical, hospital and dental use }\end{array}$ \\
Commerce & Other commerce \\
Financial intermediation and insurance & Trade in pharmaceutical, medical, orthopaedic and dental products \\
& Financial intermediation and other insurance \\
Corporate health care & Health plan -including health insurance \\
& Hospital care activities \\
Other health-care-related activities & Private social services
\end{tabular}

Source: Brazilian Geographical and Statistical Institute (IBGE), Sistema de Contas Nacionais and Contas Nacionais em Saúde, 2005. 
IV

\section{Descriptive statistics of the input-output matrix expanded to incorporate subsectors of the health sector}

Table 3 shows the relative share of the other components of the health sector in GDP, employment and gross production value in the years 2000 and 2005, respectively. The health sector as a whole represented about $7 \%$ of GDP and $4 \%$ of total employment generated in Brazil. The other subsectors include public health and other related activities. The latter's share in GDP and employment reflects the importance of the unified health system in the delivery and financing of health services. Although the pharmaceutical and medical apparatus and instruments manufacturing subsectors generate few jobs, they account for a much larger share of GDP and gross production value, thereby indicating a high capital-output ratio.

TABLE 3

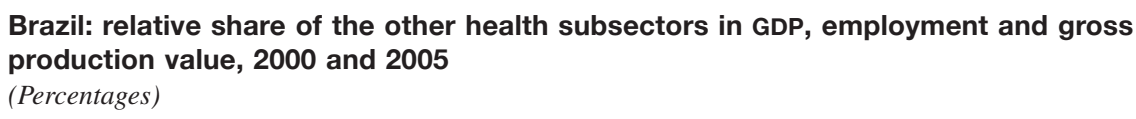

Brazil: relative share of the other health subsectors in GDP, employment and gross production value, 2000 and 2005

(Percentages)

\begin{tabular}{|c|c|c|c|c|c|c|}
\hline \multirow{2}{*}{ Subsectors } & \multicolumn{2}{|c|}{ GDP } & \multicolumn{2}{|c|}{ Employment } & \multicolumn{2}{|c|}{$\begin{array}{l}\text { Gross production } \\
\text { value }\end{array}$} \\
\hline & 2000 & 2005 & 2000 & 2005 & 2000 & 2005 \\
\hline Manufacture of pharmaceutical products & 0.71 & 0.61 & 0.05 & 0.04 & 0.70 & 0.58 \\
\hline Medical-hospital, measurement and optical apparatus and instruments & 0.32 & 0.33 & 0.12 & 0.13 & 0.29 & 0.28 \\
\hline Trade in pharmaceutical, medical, orthopaedic and dental products & 0.40 & 0.44 & 0.71 & 0.75 & 0.38 & 0.41 \\
\hline Complementary medical assistance & 0.26 & 0.19 & 0.06 & 0.07 & 0.33 & 0.22 \\
\hline Hospital care activities & 1.16 & 1.19 & 0.27 & 0.25 & 0.70 & 0.70 \\
\hline Other health-care related activities & 1.89 & 1.57 & 1.04 & 1.14 & 1.15 & 0.92 \\
\hline Private social services & 0.25 & 0.21 & 0.42 & 0.45 & 0.15 & 0.12 \\
\hline Public health & 2.47 & 2.73 & 1.37 & 1.40 & 1.45 & 1.55 \\
\hline Total & 7.46 & 7.27 & 4.04 & 4.23 & 5.16 & 4.79 \\
\hline
\end{tabular}

Source: Brazilian Geographical and Statistical Institute (IBGE), Sistema de Contas Nacionais and Contas Nacionais em Saúde, 2000 and 2005.

To identify the linkage structure of the other components of the health sector, the typical input-output analysis statistics are presented for the years 2000 and 2005. Figures 4 and 5 show the distribution of the sales of the other health subsectors for intermediate consumption and components of final demand in 2000 and 2005, respectively. For comparison purposes, the composition of the sales of large aggregate sectors are included (agriculture, extractive industry, manufacturing, commerce and services). Families account for a very small proportion of the sales of the public health sector, which is mainly consumed by government. In practice, the family consumption of public health services is counted in government consumption, because, as a free-access public good, it is not paid for (directly) by the families.
The analysis of figures 4 and 5 reveals two intersectoral relation models associated with the other health subsectors. The first group, oriented more towards industrial activity, is headed by the complementary medical care branch, which has the largest share in sales for intermediate consumption. Much of the production of those subsectors is thus converted into productive inputs for the other sectors, potentially generating upstream linkages in the economy. That group consists of the other health subsectors: manufacture of pharmaceutical products, manufacture of apparatus for medical-hospital and dental use; trade in pharmaceutical, medical, orthopaedic and dental products; and complementary medical care. The latter is linked to consumption by the public administration sector, which represents the part financed by government. 
FIGURE 4

Brazil: composition of total demand of the other health subsectors and sector aggregates by components of total absorption, 2000

( $R \$$ million $)$

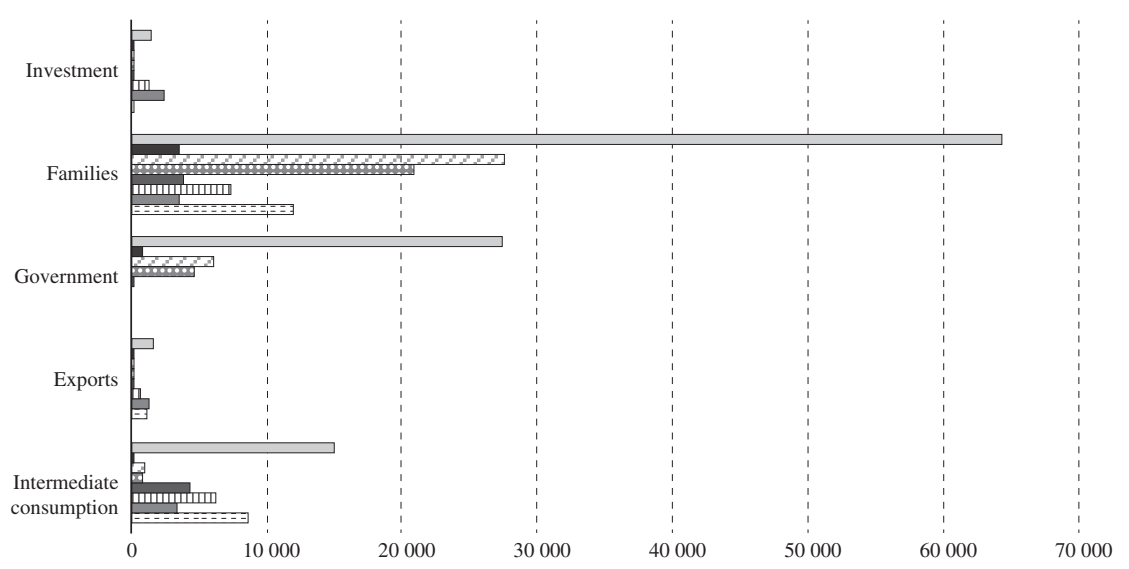

$\square$ Public health

Private social services

2 Other health-care related activities

Hospital care activities

$\square$ Supplemenary medical care

Medical-hospital, measurement and optical apparatus and instruments

III Trade in pharmaceutical, medical, orthopaedic and odontological products

ミ三 Manufacture of pharmaceutical products

Source: Brazilian Geographical and Statistical Institute (IBGE), Sistema de Contas Nacionais and Contas Nacionais em Saúde, 2000.

FIGURE 5

Brazil: composition of total demand of the other health subsectors and sector aggregates by components of total absorption, 2005

( $R \$$ million $)$

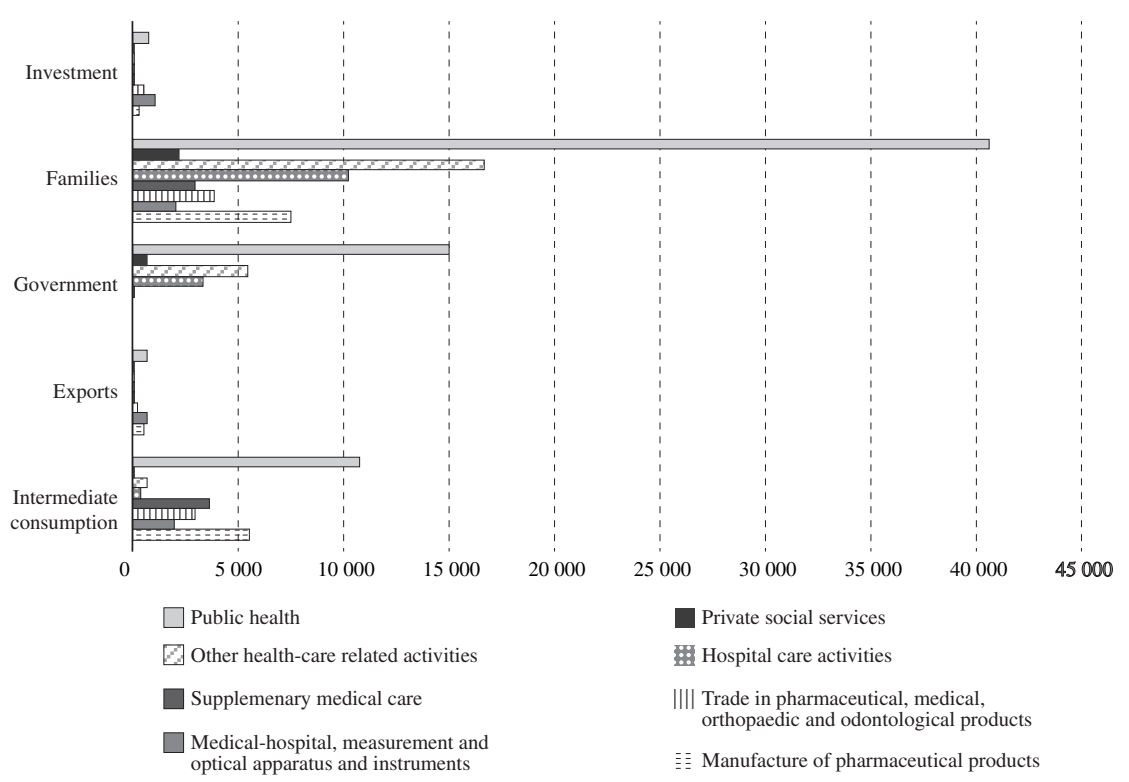

Source: Brazilian Geographical and Statistical Institute (IBGE), Sistema de Contas Nacionais and Contas Nacionais em Saúde, 2000. 
The second group of subsectors include activities related to the provision of medical care, consumed mainly by families. This group includes hospital-care activities, other health-care-related activities and private social services. The activities in question involve few upstream linkages, since they do not provide significant inputs for other sectors of the economy but basically represent final consumption services. Most of these activities are health services provided in the individual consumers' area of residence. This intersectoral relation model is repeated in the two years analysed, as is corroborated by comparing the subsectors' sales structure with that of the aggregate sectors. The first group's share of intermediate consumption is similar to that reported for manufacturing industry and commerce. It should also be noted that the Brazilian health sector basically targets domestic demand, with a very small percentage of export sales.

Table 4 displays data on the cost structure of the disaggregated health subsectors, based on domestic intermediate consumption, value-added and imports, in 2000 and 2005. Imports account for a large proportion of the costs of health subsectors that engage in industrial activities, in other words, the manufacture of pharmaceutical products and the manufacture of apparatus and instruments for medical-hospital and dental use. The share in question is similar to that seen in manufacturing industry in the two years analysed. Moreover, the share of those two subsectors in intermediate consumption is less than the industry average, which suggests few backward linkage effects in the productive structure. In addition, growth in the subsectors entails an increase in the demand for imports, which could have significant repercussions on the country's balance of payments. The cost composition of the hospital-care activities subsector is the most similar to that of industry. This probably reflects the complexity of the services provided, which are intensive both in equipment and in various national services, and it needs relatively few imports. The cost structure of the other health subsectors is similar to that of the services sector generally, with a larger share of value-added and a smaller percentage of imports.

The indicators analysed in this section displayed some of the characteristics of the health subsectors in their direct inter-relation with the other sectors of the economy, in terms of purchases, sales and costs. A complementary analysis can be performed based on the input-output model resulting from the matrix constructed with the new health subsectors.

TABLE 4

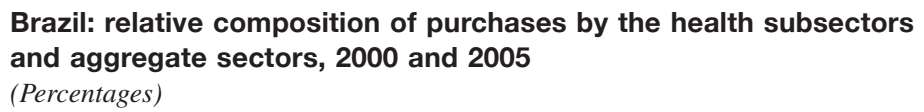

\begin{tabular}{|c|c|c|c|c|c|c|}
\hline \multirow[b]{2}{*}{ Sectors } & \multicolumn{3}{|c|}{2000} & \multicolumn{3}{|c|}{2005} \\
\hline & $\begin{array}{l}\text { Intermediate } \\
\text { consumption }\end{array}$ & Imports & Value-added & $\begin{array}{l}\text { Intermediate } \\
\text { consumption }\end{array}$ & Imports & Imports \\
\hline Manufacture of pharmaceutical products & 41.4 & 15.9 & 42.7 & 43 & 14.6 & 42.3 \\
\hline Manufacture of apparatus & 20.1 & 10.4 & 69.5 & 21.8 & 11.7 & 66.5 \\
\hline Health-care commerce & 30.8 & 0 & 69.2 & 30.5 & 0 & 69.5 \\
\hline Complementary assistance & 49.7 & 0 & 50.3 & 49.9 & 0 & 50.1 \\
\hline Hospital activities & 49.7 & 8.1 & 42.2 & 50 & 9.4 & 40.6 \\
\hline Other health-related activities & 30.8 & 5 & 64.2 & 36.1 & 6.8 & 57.1 \\
\hline Private social services & 44.4 & 7.2 & 48.4 & 39.5 & 7.5 & 53 \\
\hline Public health & 32.5 & 6.7 & 60.8 & 37 & 7.8 & 55.2 \\
\hline Agricultural & 35.6 & 4.7 & 59.8 & 41.1 & 4.8 & 54.1 \\
\hline Extractive & 45.2 & 8.5 & 46.3 & 48.9 & 8.7 & 42.4 \\
\hline Industry & 55.6 & 12.1 & 32.2 & 57.6 & 12.1 & 30 \\
\hline Commerce & 24.8 & 5.1 & 70.1 & 24.9 & 5.2 & 69.9 \\
\hline Services & 31 & 4.6 & 64.4 & 30.9 & 5.2 & 63.9 \\
\hline
\end{tabular}

Source: Brazilian Geographical and Statistical Institute (IBGE), Sistema de Contas Nacionais and Contas Nacionais em Saúde, 2000. 


\section{V}

\section{Analysis of health subsectors based on the input-output model}

Multiplier analysis is a traditional approach derived from the input-output model. Multipliers complement the analysis of the importance of a given sector in the economy, making it possible to evaluate the direct and indirect effects on the economic system of exogenous disturbances, particularly from final demand (Miller and Blair, 2009). This study uses the most common input-output indicators: production and employment multipliers, indices of backward and forward linkages and key sector. These indicators are constructed according to the methodology described in Miller and Blair (2009).

In short, production multipliers capture the effect on the economy's production of a one-monetary-unit increase in the sector's final demand. Thus, as the increase in final demand for the sector's production implies a need for direct inputs, which in turn require more inputs, the indirect need of production is essential for satisfying that demand. The total coefficients of the Leontief inverse matrix capture that effect in all sectors, whereas summation along the rows measures the total multiplier effect of the sector in question. Similarly, assuming employment has a fixed-coefficient relation with the sectors' production, the production multiplier effects would be reflected in employment multiplier effects. Lastly, the index of backward and forward linkage and the key sector are formulations based on the multipliers, where the aim is to identify the sectors that contribute by more than the economy-average in terms of multiplier effects on input purchases (backward linkage) and on the sale of their output (forward linkages). Annex II formalizes these indicators.

A complementary approach to key sector concept and linkage indices is the field of influence (Sonis and Hewings, 1992).

The field-of-influence concept relates directly to changes in the technical input-output coefficients, defined as follows:
$A=\left\|a_{i j}\right\|$ is the direct coefficients matrix;

$E=\left\|e_{i j}\right\|$ is the matrix of disturbances;

$B=(I-A)^{-1}=\left\|b_{i j}\right\|$ is the inverse Leontief matrix before the effects of the disturbances;

$B(\varepsilon)=(I-A-E)^{-1}=\left\|b_{i j}(\varepsilon)\right\|$ is the inverse Leontief matrix after the effects of the disturbances.

Assume a small change $\varepsilon$, in just one parameter, $a_{i j}$ of matrix $A$. For example, let $i=1$ and $j=1$, such that:

$$
E_{i j}=\left\{\begin{array}{ll}
\varepsilon, \text { se } & i=1, j=1 \\
0, \text { se } & i \neq 1, j \neq 1
\end{array}\right\}
$$

According to Sonis and Hewings (1992), the field of influence stems from the following relation:

$$
F\left(\varepsilon_{i j}\right)=\frac{\left\lfloor B\left(\varepsilon i_{j}\right)-B\right\rfloor}{\varepsilon_{i j}}
$$

where $F\left(\varepsilon_{i j}\right)$ is the field of influence of the change in the input-output coefficient $a_{i j}$. According to Guilhoto (2004), to identify the coefficients with the largest field of influence, it would be necessary to associate each matrix $F\left(\varepsilon_{i j}\right)$ with a value equal to:

$$
S_{i j}=\sum_{k=1}^{n} \sum_{l=1}^{n}\left[f_{k l}\left(\varepsilon_{i j}\right)\right]^{2}
$$

Thus, from the value $S_{i j}$ it is possible to develop a hierarchy of direct coefficients based on their respective fields of influence. In other words, the sectoral relations can be viewed in terms of their importance in the multiplier effect in the economy. 


\section{VI}

\section{Results}

This section presents the results obtained from the analysis of the linkages of the health subsectors in the context of the Brazilian economy, using an input-output model and its usual indicators: (i) simple multipliers of production and employment; (ii) linkage indicators; (iii) key sector, and (iv) field of influence.

The forward and backward linkage indices can be used to evaluate the interaction between the subsectors, with respect to both the supply of intermediate inputs and the demand for them. As a result, key subsectors are considered those that have above-average linkages in both the purchase and the sale of their output to the rest of the national economy.

Annex III sets out the results of the forward and backward linkage indices and the identification of key sectors. Those results are illustrated in figures 6 and 7 , which relate the forward and backward linkage indices to the specification of the key sectors in 2000 and 2005. The horizontal axis measures the forward linkage index in each sector, and the vertical axis indicates the backward linkage index.

Quadrant I of figures 6 and 7 shows the key sectors, in other words those with above-average input purchase and sale linkages to the rest of the economy. Quadrant II shows sectors that have above-average forward and below-average backward linkages, in other words, while the sale of their products in money terms is greater than the average for the rest of the economy, their input purchases are below average. Quadrant III shows sectors that have a low level of production linkage, with few intersectoral relations in either the sale or the purchase of products on the domestic market. Lastly, although the sectors of quadrant IV purchase more than average amounts of domestic intermediate inputs, they are little used as production inputs themselves.

The results show that none of the health subsectors was a key sector of the economy, either in 2000 (see figure 6) or in 2005 (see figure 7). This result was expected, since the service sectors generally have few backward and forward linkages; they are more closely related to final demand (consumption by families and government), and make intensive use of imported inputs (pharmaceuticals sector).

The key sectors identified for the Brazilian economy were: (i) food and beverages; (ii) textiles; (iii) cellulose and paper products; (iv) oil refining; (v) chemical products; (vi) manufacture of resins and elastomers; (vii) articles of rubber and plastic; (viii) manufacture of steel and products of steel, and (ix) metal products, except machinery and equipment. There were no changes in the list of key sectors between the two periods.

FIGURE 6

Brazil: dispersion of backward and forward linkages, 2000

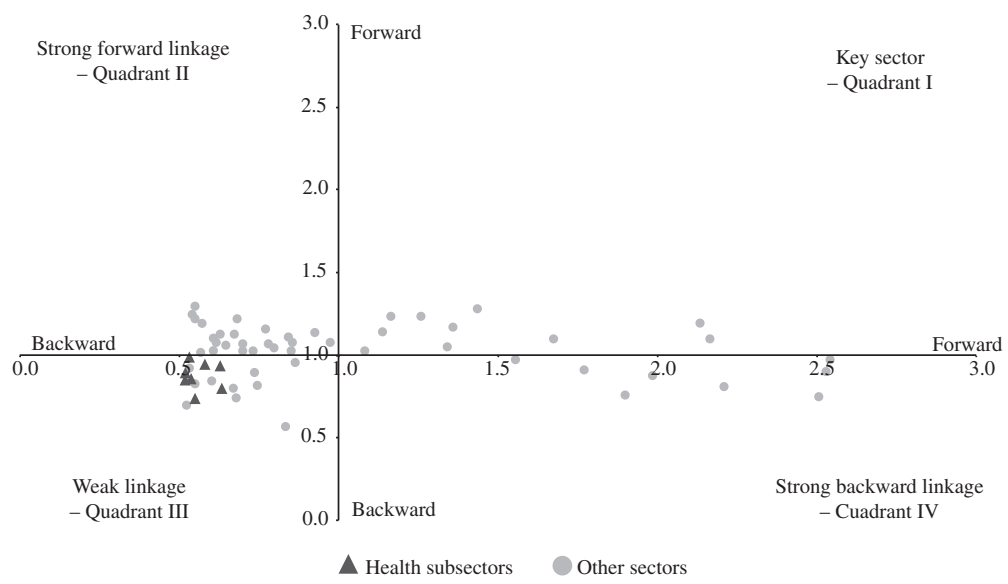

Source: Prepared by the authors. 
FIGURE 7

Brazil: dispersion of backward and forward linkages, 2005

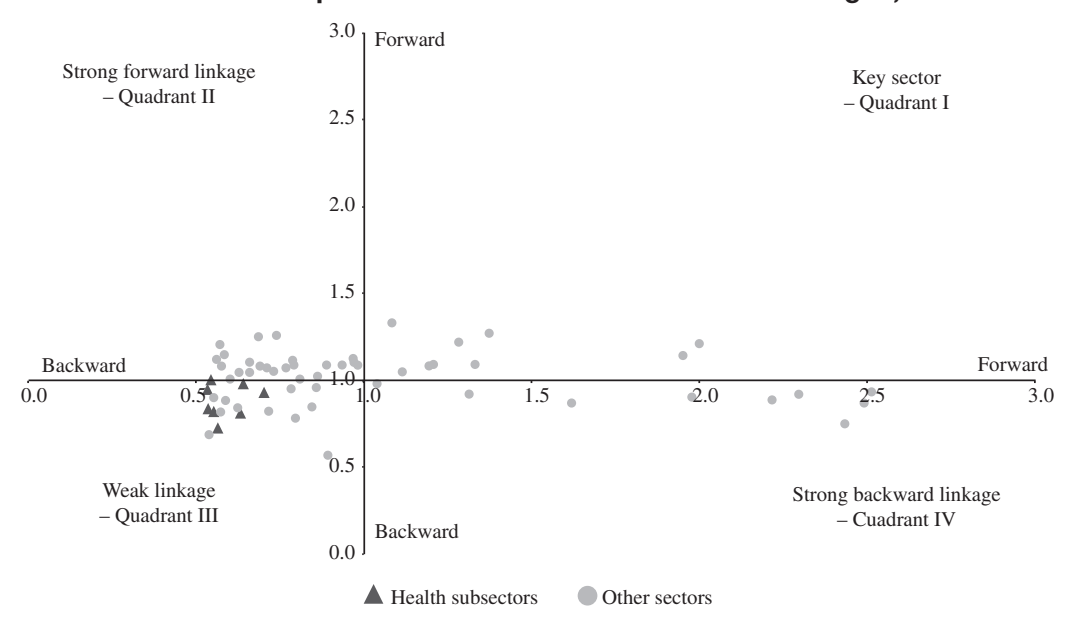

Source: Prepared by the authors.

A more detailed view of the health subsector multipliers reveals their lower-than-economy-average effect. The production multiplier corresponds to a direct and indirect variation in the total production of the economy (all sectors), stemming from an exogenous change of one monetary unit of final demand in a given sector. As a substantial part of the subsectors' sales corresponds to final demand, and their intermediate purchase coefficients are small, one would expect these subsectors to rank low in terms of linkages.

Annex IV shows the results of the multipliers for Brazil in the period analysed (2000 and 2005). These figures are similar in the two years, because the inputoutput structure changes little through time. The simple production multipliers of the health subsectors (see table 5) displayed below-average values (1.88 in 2000 and 1.92 in 2005), compared to the other sectors of the economy (see annex IV). The services sectors generally have few upstream linkages, because their sales are destined mainly for final demand. Moreover, as explained in section III, the high import coefficients imply less multiplier effects on the national economy, which is characteristic of the pharmaceuticals manufacturing and hospital-care activities sectors, for example. Among the various health subsectors, hospital-care activities recorded the largest production multipliers in 2000 and 2005: 1.87 and 1.88 , respectively (33rd and 35th in the ranking of the multiplier effects in the economy). In this case, an increase of one real in the production of hospital-care activities generates a 1.89 reais increase in final demand in the economy.
Associated with the production multipliers, the employment multipliers indicate the number of jobs created in the economy for each job created in the sector of interest, incorporating the direct and indirect effects of a variation in final demand.

Table 6 reports the employment multipliers of the health subsectors. An increase of one million reais in final demand produced an average of 59 jobs in 2000 and 38 in 2005. The employment multipliers fall in all sectors between 2000 and 2005, possibly reflecting productivity gains during the period (see annex IV). In the two years analysed, the multipliers of the private social services and health services trade sectors were above the national average. The private social services sector has the fourth largest sector employment multiplier, with 103 jobs created in the economy as a result of a change of $\mathrm{R} \$ 1$ million in final demand in 2005. This reflects the subsector's high labour intensity. The health services trade and other health-related activities subsectors also generated jobs at a rate above the average for the Brazilian economy as a whole (see table 6).

The field of influence, as calculated in equation (3) defines the importance of each of the purchase and sale relations (input-output), both intersectoral and intrasectoral. Table 7 shows the field of influence of the input- output model corresponding to 2005 . For ease of viewing, the results for each productive link are shown in grey scales, representing above-average fields of influence, in other words, the most important linkages for the economy in general. Those links were classified into four groups: (i) Group A: linkages that display one standard deviation 
TABLE 6

Employment multipliers, 2000 and 2005

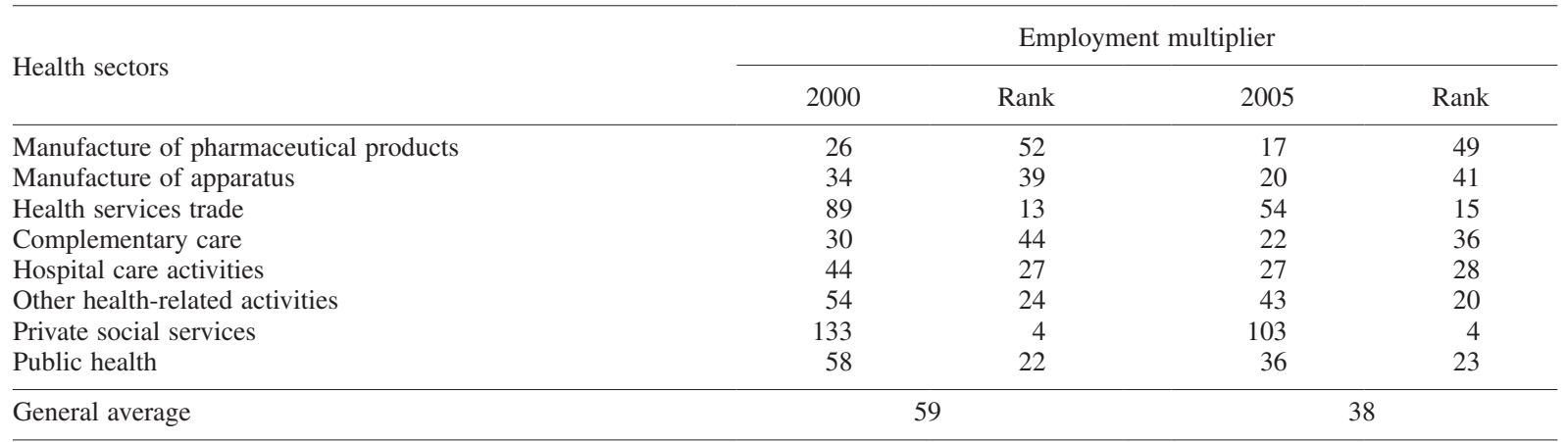

Source: Brazilian Geography and Statistical Institute (IBGE), Sistema de Contas Nacionais and Contas Nacionais em Saúde, 2000.

above the mean (light grey); (ii) Group B: between one and two standard deviations above the mean (medium grey); (iii) Group C: between two and three standard deviations above the mean (dark grey); and (iv) Group D: more than three standard deviations above the mean (darker colour). Following the input-output structure, the rows correspond to the sectors that supply productive inputs, whereas the columns represent the destination of those inputs. The rows and columns labeled 18 and 19 refer to the health subsectors.

The results showed few significant links in health subsectors, compared with other sectors. The specific results in 2005 for the subsectors "Manufacture of pharmaceutical products (18)", "Manufacture of apparatus for medical-hospital and dental use (19)" and "Complementary medical care (48)" are noteworthy. The results of the field of influence for 2000 repeat the pattern (see annex V). The sector "Manufacture of pharmaceutical products (18)" has close links with sectors from other areas of the economy, including the food and beverages (6), textiles (8), cellulose and paper products (12), oil and coke refining (14), and electricity and gas, water, sewerage and urban cleaning (41) sectors. The main upstream linkage of the health subsectors in the economy occurs through the purchases of the pharmaceuticals subsector. In terms of intrasectoral interdependence, it is strongly linked with the subsector "Complementary medical care (48)."

In terms of the intensity of the linkages of the health subsectors:

(i) The subsector "Manufacture of pharmaceutical products (18)" displays seven above-average linkages with respect to the subsector's purchases and 12 above-average linkages in relation to its sales.

(ii) The subsector "Manufacture of apparatus for medical-hospital and dental use" displays seven above-average linkages with respect to the subsector's purchases and 10 above-average linkages in relation to its sales.

(iii) The subsector "Complementary medical care (48)" displays seven above-average linkages with respect to the subsector's purchases and 14 above-average linkages with respect to its sales.

(iv) The intensity of the intersectoral linkages (within the group of subsectors that comprise the health sector) is not very strong, in terms of either sales or purchases. They are represented by lines 44, 48, 54, 55, 56 and 59, which show linkages with a below-average standard deviation. In some cases the linkages are below this pattern. 


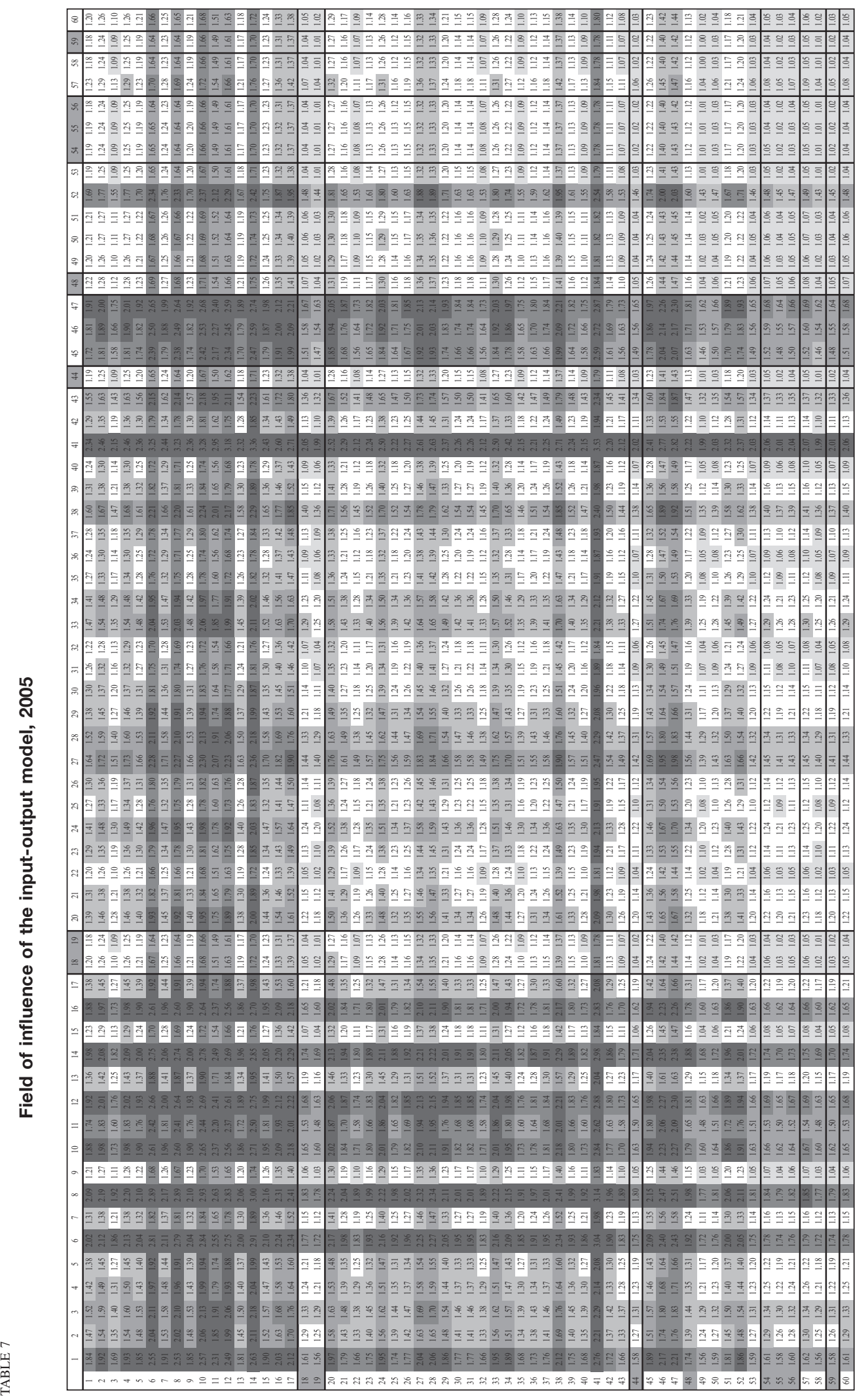




\section{VII}

\section{Final comments}

This article contributes to the study of health economics by constructing an input-output matrix with a subsector breakdown of the sectors analysed, thereby making it possible to evaluate their productive linkages. The harmonization and integration of the input-output matrix with the National Health Accounts System for the years 2000 and 2005 opens up a major research agenda in the field of health economics, by allowing for analysis and evaluation of public policies in that area. To better understand the reforms of the Brazilian health system, account needs to be taken of their macroeconomic effects on productive chains and job creation, bearing in mind the importance of the sector from the individual- and social-welfare standpoints.

This article's broad characterization of the health sector, and its integration into the productive structure of the economy, produces a number of general results pertaining to the dynamic of the sector in Brazil. Firstly, intersectoral relations in the health subsectors are quite concentrated, since most of the sales represent final demand by families or intermediate consumption by the sector itself. This results in few backward and forward linkage effects. Two other characteristics of the sector's productive structure are the highly intensive use of labour and orientation toward generating medical services as such. The subsectors linked to the production of pharmaceutical products and medical apparatus are an exception to the pattern, and are more similar to the industrial sectors. Accordingly, they are the health subsectors with the strongest domestic and external linkages.

Other structural characteristics of the health sector in 2000 and 2005 include the fact that the main destinations for the production of the pharmaceuticals manufacturing subsector are intermediate consumption and consumption by families; and this subsector requires a large amount of imported inputs compared to the other health subsectors. In the case of the employment multipliers, there are health subsectors with a high multiplier effect, such as private social services (ranked fourth), and also subsectors with a low multiplier effect, such as the manufacture of pharmaceuticals (ranked 49th in 2005).

Lastly, another result concerns the productive linkage of the health subsectors. The field of influence showed that the pharmaceutical product manufacturing subsector, which has the strongest relation with the other sectors, has clear linkages with the food and beverages, textiles, cellulose and paper products, electricity and gas, water, sewerage and urban cleaning sectors. This result clarifies the productive chain of this health subsector and illustrates its likely repercussions on the productive sector of the economy as a result of policies to encourage the manufacture of pharmaceutical products, among other things.

From the standpoint of long-term sector policies, the results suggest that the effects of a general increase in health expenditure on Brazil's productive structure are less intensive than the average of the other sectors of the economy, owing to the health sector's low degree of backward and forward linkage. Those effects could be more important in the pharmaceuticals and hospital-care subsectors specifically. Population ageing will probably generate expenditure growth, particularly in those subsectors. This paper, based on the harmonization of the Brazilian input-output matrix, represents an important step enabling this type of research.

Thus, the systemic treatment of the health sector, in other words evaluating its interdependence with the productive fabric of an economy such as Brazil's, constitutes a new research agenda in a country that is undergoing changes, such as the demographic transition and variations in the individuals' consumption basket and in life expectancy, which could have repercussions for the behaviour of this sector. This study is seminal for the Brazilian economy because it provides a starting point for expanding the line of research in using the matrix developed here to calibrate computable general equilibrium models and, for example, perform a welfare analysis. 
ANNEX I

The first step in the preparation of the data consisted of expanding the matrix of resources of goods and services to incorporate the health subsectors. A 110x60 matrix was obtained. For that purpose, the matrix of resources of goods and services of the National Health Accounts was used, assuming the same production technology for all of the products of a given industry. Under that hypothesis, the activity $\mathrm{x}$ product matrix was constructed (market share or D matrix), the coefficients of which are obtained by normalizing their values with respect to the total amount of each product produced. The resulting matrix provides data on the share of each product originating from the various sectors of economic activity.

The second stage was to expand the matrix of the supply of and demand for production at basic prices to incorporate the health subsectors; and the table of uses of goods and services of the satellite accounts for that sector were used for that purpose. As a result, a matrix of monetary flows with technology-product $\mathrm{x}$ sector (110x60) was obtained, along with intermediate consumption flows and final-demand values.

The final step consisted of transforming the matrix of supply and demand for production (constructed through the second stage) into a square matrix, using the following procedure: multiplication of the marketshare matrix (constructed on the basis of the first step) transposed, in other words, a 60x110 matrix, by the matrix of supply and demand for production (constructed in B), in other words a 110x60 matrix. A 60x60 matrix was thus obtained. Value added, obtained from the matrix of uses of goods and services at consumer prices, was incorporated into the 60x 60 input-output matrix. For the data on health-sector value-added, the uses of goods and services of the National Health Accounts was used. With respect to the closure of the matrix from the purchases standpoint, the value of imports was calculated as the difference between the total value of production and the sum of intermediate consumption and value-added.

The statistics available for the health sector in Brazil based on the satellite accounts are quite detailed. There are data on demand (final consumption, consumption of public administration, investment, government) and value-added, data relating to the use of domestic and imported inputs, tables on the production of the activities and a breakdown by margins and taxes.

This makes it possible to decompose the matrix and construct technical coefficients, taking account of the specifics of the products and sectors. Tables relating to the health sector in Brazil, obtained from the satellite accounts, make it possible to capture the orientation of the sales of products and sectors, for both intermediate and final consumption. This is of the utmost importance in this study, since the breakdown proposed presents a number of sectors that are oriented more towards intermediate consumption and others oriented towards final demand (for example private social services).

To gain a better idea of the structure of the accounts, an extract is reproduced below. 
TABLE A. 1

\section{Resources of goods and services}

\begin{tabular}{|c|c|c|c|c|c|}
\hline \multirow[b]{2}{*}{ Product description } & \multicolumn{5}{|c|}{ Output of the activities (previous year's prices in $R \$$ million) } \\
\hline & $\begin{array}{c}\text { Manufacture of } \\
\text { pharmaceutical } \\
\text { products }\end{array}$ & $\begin{array}{l}\text { Manufacture } \\
\text { of apparatus } \\
\text { for medical- } \\
\text { hospital and } \\
\text { dental use }\end{array}$ & $\begin{array}{c}\text { Trade in } \\
\text { pharmaceutical, m } \\
\text { edical, orthopaedic } \\
\text { and dental } \\
\text { products }\end{array}$ & $\begin{array}{l}\text { Complementary } \\
\text { medical care }\end{array}$ & Public health \\
\hline Medications for human use & 12307 & 0 & 0 & 0 & 13 \\
\hline Medications for veterinary use & 1650 & 0 & 0 & 0 & 0 \\
\hline Materials for medical, hospital and dental use & 653 & 14 & 0 & 0 & 0 \\
\hline $\begin{array}{l}\text { Apparatus and instruments for medical, hospital and } \\
\text { dental use }\end{array}$ & 3 & 2644 & 0 & 0 & 0 \\
\hline $\begin{array}{l}\text { Trade in pharmaceutical, medical, orthopaedic and } \\
\text { dental products }\end{array}$ & 0 & 0 & 7541 & 0 & 0 \\
\hline Public health & 0 & 0 & 0 & 0 & 29506 \\
\hline Hospital care services & 0 & 0 & 0 & 0 & 1200 \\
\hline Other health-care-related services & 0 & 0 & 0 & 0 & 8 \\
\hline Private social services & 0 & 0 & 0 & 0 & 0 \\
\hline Agriculture & 0 & 0 & 0 & 0 & 0 \\
\hline Mining industry & 0 & 0 & 0 & 0 & 0 \\
\hline Manufacturing industry & 828 & 9 & 0 & 0 & 1 \\
\hline $\begin{array}{l}\text { Production and distribution of electricity, } \\
\text { gas and water }\end{array}$ & 0 & 0 & 0 & 0 & 0 \\
\hline Construction & 0 & 0 & 3 & 0 & 0 \\
\hline Commerce & 0 & 0 & 0 & 0 & 0 \\
\hline Transport, storage and postal services & 0 & 0 & 0 & 0 & 0 \\
\hline Information services & 0 & 0 & 0 & 0 & 0 \\
\hline $\begin{array}{l}\text { Financial intermediation, insurance and } \\
\text { complementary pension saving }\end{array}$ & 0 & 0 & 0 & 0 & 0 \\
\hline Public administration, health and education & 0 & 0 & 0 & 0 & 0 \\
\hline CIF/FOB adjustment & - & - & - & - & - \\
\hline Total & 15766 & 2667 & 7560 & 7566 & 30728 \\
\hline
\end{tabular}


Table A.1 (concluded)

\begin{tabular}{|c|c|c|c|c|c|}
\hline \multirow[b]{2}{*}{ Product description } & \multicolumn{5}{|c|}{ Output of the activities (previous year's prices in $R \$$ million) } \\
\hline & $\begin{array}{l}\text { Manufacture of } \\
\text { pharmaceutical } \\
\text { products }\end{array}$ & $\begin{array}{l}\text { Manufacture } \\
\text { of apparatus } \\
\text { for medical- } \\
\text { hospital and } \\
\text { dental use }\end{array}$ & $\begin{array}{c}\text { Trade in } \\
\text { pharmaceutical, } \\
\text { medical, } \\
\text { orthopaedic and } \\
\text { dental products }\end{array}$ & $\begin{array}{l}\text { Complementary } \\
\text { medical care }\end{array}$ & Public health \\
\hline Pharmaco-chemical products & 0 & 0 & 0 & 2 & 312 \\
\hline Medications for human use & 0 & 0 & 0 & 95 & 12415 \\
\hline Medications for veterinary use & 0 & 0 & 0 & 245 & 1895 \\
\hline Materials for medical, hospital and dental use & 0 & 0 & 0 & 6 & 673 \\
\hline $\begin{array}{l}\text { Apparatus and instruments for medical, hospital and } \\
\text { dental use }\end{array}$ & 0 & 0 & 0 & 8 & 2655 \\
\hline $\begin{array}{l}\text { Trade in pharmaceutical, medical, orthopaedic and } \\
\text { dental products }\end{array}$ & 0 & 0 & 0 & 0 & 7541 \\
\hline Health plans _including health insurance & 0 & 0 & 0 & 0 & 7561 \\
\hline Public health & 0 & 0 & 0 & 0 & 29506 \\
\hline Hospital care services & 13590 & 0 & 0 & 281 & 15071 \\
\hline Other health-care-related services & 0 & 22783 & 0 & 0 & 22791 \\
\hline Private social services & 0 & 0 & 1464 & 0 & 1464 \\
\hline Agriculture & 0 & 0 & 0 & 91708 & 91708 \\
\hline Mining industry & 0 & 0 & 0 & 36997 & 36997 \\
\hline Manufacturing industry & 0 & 0 & 0 & 626595 & 627433 \\
\hline $\begin{array}{l}\text { Production and distribution of electricity, gas and } \\
\text { water }\end{array}$ & 0 & 0 & 0 & 64030 & 64030 \\
\hline Construction & 0 & 0 & 0 & 110119 & 110122 \\
\hline Commerce & 0 & 0 & 666 & 145977 & 146643 \\
\hline Transport, storage and postal services & 0 & 0 & 0 & 96271 & 96271 \\
\hline Information services & 0 & 0 & 0 & 76606 & 76606 \\
\hline $\begin{array}{l}\text { Financial intermediation, insurance and } \\
\text { complementary pension saving }\end{array}$ & 0 & 0 & 0 & 103258 & 103258 \\
\hline Real estate and rental activities & 700 & 382 & 893 & 139395 & 141406 \\
\hline Other services & 0 & 0 & 0 & 226185 & 226185 \\
\hline Public administration, health and education & 0 & 0 & 0 & 193210 & 193210 \\
\hline CIF/FOB adjustment & - & - & - & - & - \\
\hline Total & 14290 & 23165 & 3023 & 1910988 & 2015753 \\
\hline
\end{tabular}

Source: Brazilian Geographical and Statistical Institute (IBGE), Health Satellite Accounts.

Note: CIF: Cost, insurance and freight; FOB: Includes the value of the goods and expenses of transportation to the destination country.

The breakdown structure of the satellite accounts reveals differences in the production structure. To verify the technological differences, an extract of the inverse
Leontief matrix is shown below, with the health subsectors highlighted. The "technological" specifics of each sector can thus be viewed. 


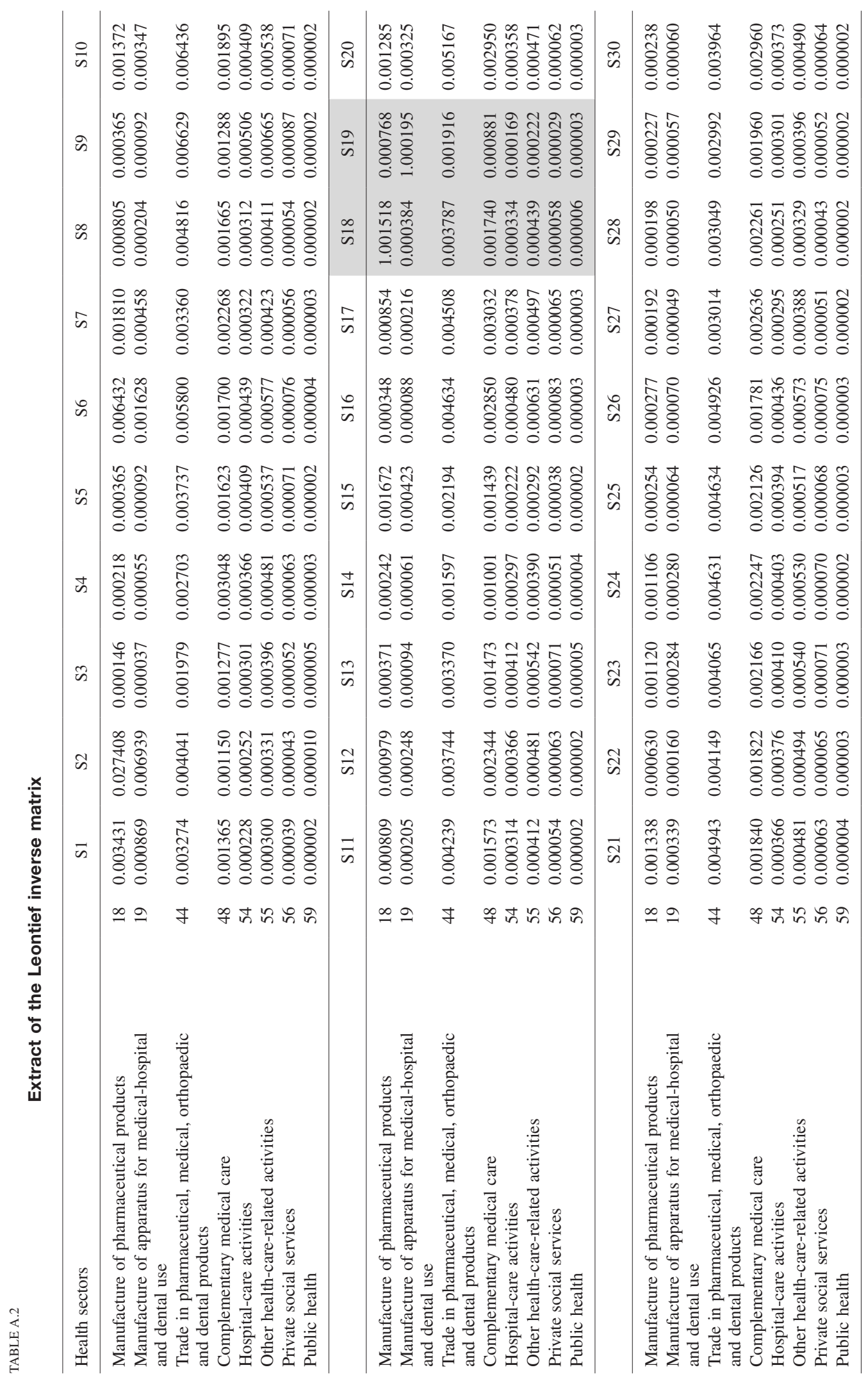




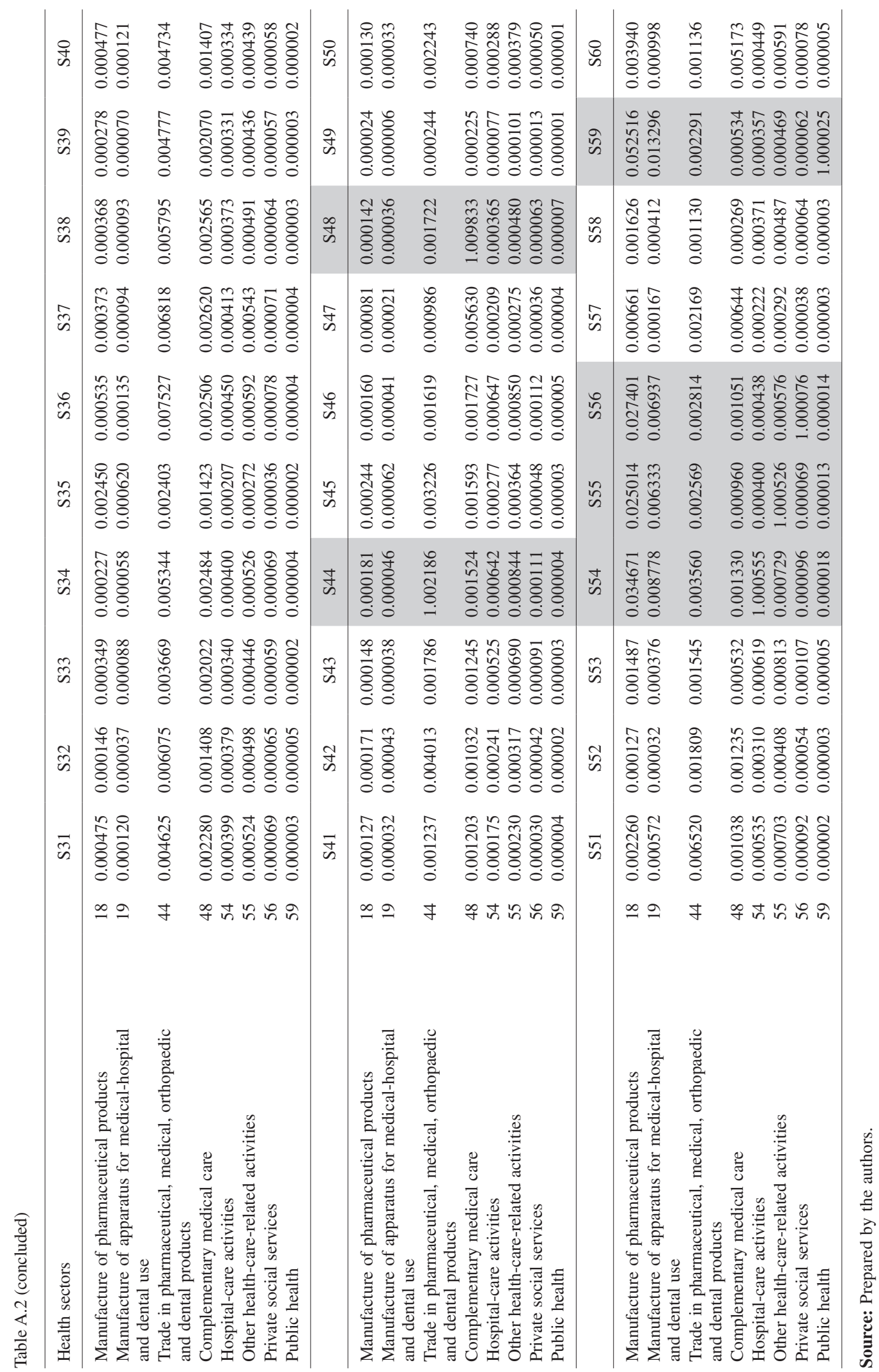


ANNEX II

\section{Formal construction of input-output indicators}

The multipliers complement the analysis of the importance of a given sector in the economy, by making it possible to evaluate the short and long-term effects produced in a given economic system by exogenous disturbances (Miller and Blair, 2009).

The production multiplier measures the direct and indirect variation in the total production of an economy of all sectors and regions, caused by an exogenous variation of one monetary unit in the final demand of a given region or sector. In formal terms, the simple output multiplier for sector $j, O j$, is given by:

$$
O_{j}=\sum_{i=1}^{n} b_{i j}
$$

where $b_{i j}$ are the elements of the inverse Leontief matrix.

The employment multiplier estimates the effects of an exogenous change in final demand, in other words the number of jobs generated in the economy, either directly or indirectly, by a change in final demand that is sufficient to cause an increase in employment in sector $j$. Calculating the employment multiplier entails estimating the relation between the value of production of a given sector and employment in that sector. In formal terms:

$$
w_{n+1, j}=e_{j} / X_{j}
$$

where $e_{j}$ represents personnel employed in sector $j$, and $X_{j}$ is that sector's gross production value.

For an economy with $n$ sectors:

$$
W_{R}=\left\lfloor w_{n+1,1}, w_{n+1,2}, \cdots, w_{n+1, n}\right\rfloor
$$

So the simple employment multiplier is given by:

$$
E_{j}=\sum_{i=1}^{n} w_{n+1, i} b_{i j}
$$

where $i$ represents a given sector of the economy and $w_{n+1, i}$ is the ratio between the number of employees and the value of production.

The matrix that results from that transformation $\left(E_{j}\right)$ represents the sector capacity for generating employment per additional unit of final demand. The structure of the matrix $E_{j}$ is similar to the structure of the matrices B (Leontief) and A (coefficients matrix). Consequently, for each sector $j$, the sum of the elements of each column represent the employment multiplier of sector $j$.

Rasmussen (1952) and Hirschman (1958) use backward and forward linkage indices to identify the sectors with the greatest linkage power in the economy. The backward linkages (power of dispersion) $-U_{j}-$ determine how much a given sector demands from the other sectors of the economy, whereas the forward linkages (sensitivity of dispersion) $-U_{i}-$ determine the degree to which that sector supplies demand from the other sectors the economy. The backward linkage index is defined as:

$U_{j}=\frac{1}{n} \sum_{i} b_{i j} / \frac{1}{n^{2}} \sum_{i} \sum_{j} b_{i j} \quad(i, j=1,2, \ldots, n)(\mathrm{A} .5)$

The forward linkage index is defined as:

$U_{i}=\frac{1}{n} \sum_{j} b_{i j} / \frac{1}{n^{2}} \sum_{i} \sum_{j} b_{i j} \quad(i, j=1,2, \ldots, n)$ (A.6)

If $U_{j}>1$, a unit variation in the final demand of sector $j$ creates an above-average increase in the economy. If $U_{i}>1$, a unit change in the final demand of all sectors creates an above average increase in the sector. Values above 1 in both indices identify key sectors in the economy. Those sectors have strong linkage effects in terms of the flow of goods and services, and make above-average contributions to the growth of the economy. 
ANNEX III

TABLE A.3

Brazil: index of linkages and key sectors, 2000 and 2005

\begin{tabular}{|c|c|c|c|c|c|c|}
\hline \multirow{2}{*}{ Economic sectors } & \multicolumn{2}{|c|}{ Backward linkages } & \multicolumn{2}{|c|}{ Forward linkages } & \multicolumn{2}{|c|}{ Key sector } \\
\hline & 2000 & 2005 & 2000 & 2005 & 2000 & 2005 \\
\hline Agriculture, forestry, forestry management & 0.8673 & 0.9086 & 1.6158 & 1.7715 & - & - \\
\hline Livestock and fishing & 0.9629 & 1.0238 & 0.8550 & 0.8492 & - & - \\
\hline Oil and natural gas & 0.9220 & 0.9692 & 1.3107 & 1.5526 & - & - \\
\hline Iron ore & 1.0807 & 1.0224 & 0.6876 & 0.7293 & - & - \\
\hline Other extractive industry & 1.0227 & 1.0500 & 0.8594 & 0.7967 & - & - \\
\hline Food and beverages & 1.2718 & 1.2796 & 1.3742 & 1.4364 & $\mathrm{X}$ & $\mathrm{X}$ \\
\hline Tobacco products & 1.1258 & 1.2408 & 0.5625 & 0.5469 & - & - \\
\hline Textiles & 1.0525 & 1.0254 & 1.1146 & 1.0826 & $\mathrm{X}$ & $\mathrm{X}$ \\
\hline Garments and accessories & 1.0082 & 1.0241 & 0.5989 & 0.5657 & - & - \\
\hline Leather and footwear articles & 1.2511 & 1.2159 & 0.6824 & 0.6822 & - & - \\
\hline Products onward except furniture & 1.0114 & 1.1063 & 0.8078 & 0.8406 & - & - \\
\hline Cellulose and the likes of paper & 1.0942 & 1.1403 & 1.2073 & 1.1404 & $\mathrm{X}$ & $\mathrm{X}$ \\
\hline Newspapers, magazines and discs & 0.9844 & 0.9532 & 1.0359 & 0.8628 & - & - \\
\hline Oil and coke refining & 1.2119 & 1.1900 & 1.9997 & 2.1330 & $\mathrm{X}$ & $\mathrm{X}$ \\
\hline Alcohol & 1.0934 & 1.0238 & 0.7921 & 0.7015 & - & - \\
\hline Chemical products & 1.1452 & 1.0975 & 1.9503 & 2.1663 & $\mathrm{X}$ & $\mathrm{X}$ \\
\hline Manufacture of resins and elastomers & 1.3315 & 1.2331 & 1.0811 & 1.1639 & $\mathrm{X}$ & $X$ \\
\hline Manufacture of pharmaceutical products & 0.9313 & 0.9292 & 0.7023 & 0.6315 & - & - \\
\hline Manufacture of apparatus for medical-hospital and medical use & 0.7266 & 0.7272 & 0.5637 & 0.5485 & - & - \\
\hline Pesticides & 1.2635 & 1.1579 & 0.7379 & 0.7721 & - & - \\
\hline Perfume, hygiene and cleaning & 1.0712 & 1.1283 & 0.7093 & 0.6286 & - & - \\
\hline Paints, varnishes, enamels and lacquers & 1.1129 & 1.0757 & 0.6563 & 0.6185 & - & - \\
\hline Products and preparations of miscellaneous chemicals & 1.0946 & 1.0787 & 0.8872 & 0.8494 & - & - \\
\hline Articles of rubber and plastic & 1.2183 & 1.1675 & 1.2801 & 1.3594 & $\mathrm{X}$ & $\mathrm{X}$ \\
\hline Cement & 1.0467 & 1.1025 & 0.6274 & 0.6087 & - & - \\
\hline Other nonmetallic mineral products & 1.1245 & 1.0734 & 0.7881 & 0.7804 & - & - \\
\hline Manufacture of steel and steel products & 1.0944 & 1.0989 & 1.3294 & 1.6753 & $\mathrm{X}$ & $\mathrm{X}$ \\
\hline Non ferrous metallurgy & 1.0882 & 1.0197 & 0.9302 & 0.8489 & - & - \\
\hline Products of metal, except machinery and equipment & 1.0836 & 1.0515 & 1.1956 & 1.3435 & $\mathrm{X}$ & $\mathrm{X}$ \\
\hline Machinery and equipment, including maintenance and repairs & 1.1059 & 1.1290 & 0.9712 & 0.9253 & - & - \\
\hline Electrical appliances & 1.2088 & 1.2245 & 0.5708 & 0.5478 & - & - \\
\hline Office machinery and computer hardware & 0.8997 & 0.9179 & 0.5525 & 0.5306 & - & - \\
\hline Electrical machines, apparatus and materials & 1.0944 & 1.0729 & 0.9819 & 0.9758 & - & - \\
\hline Electronic material and communication equipment & 1.0540 & 1.0635 & 0.7272 & 0.6465 & - & - \\
\hline $\begin{array}{l}\text { Medical-hospital, measurement and optical apparatus and } \\
\text { instruments }\end{array}$ & 0.8435 & 0.8426 & 0.6242 & 0.6008 & - & - \\
\hline Automobiles, trucks and utility vehicles & 1.1507 & 1.2981 & 0.5815 & 0.5500 & - & - \\
\hline Trucks and buses & 1.0829 & 1.1955 & 0.5731 & 0.5733 & - & - \\
\hline Parts and accessories for automotive vehicles & 1.1286 & 1.2395 & 0.9680 & 1.2576 & - & - \\
\hline Other transport equipment & 0.8862 & 1.1223 & 0.5860 & 0.6755 & - & - \\
\hline Furniture and products on various industries & 1.0493 & 1.0252 & 0.6573 & 0.6066 & - & - \\
\hline Electricity and gas, water, sewerage and urban cleaning & 0.9196 & 0.8993 & 2.2950 & 2.5283 & - & - \\
\hline Construction & 0.9552 & 0.8919 & 0.7809 & 0.7343 & - & - \\
\hline Trade in other health services & 0.7532 & 0.7443 & 2.4336 & 2.5043 & - & - \\
\hline Trade in pharmaceutical, medical, orthopaedic and dental products & 0.8068 & 0.7945 & 0.6318 & 0.6322 & - & - \\
\hline Transport, storage and postal services & 0.9298 & 0.9719 & 2.5105 & 2.5416 & - & - \\
\hline Information services & 0.9017 & 0.8753 & 1.9773 & 1.9822 & - & - \\
\hline Financial intermediation and other insurance & 0.8835 & 0.7574 & 2.2145 & 1.8974 & - & - \\
\hline Complementary medical care & 0.9767 & 0.9343 & 0.6406 & 0.5811 & - & - \\
\hline Real estate and rental services & 0.5732 & 0.5661 & 0.8905 & 0.8335 & - & - \\
\hline Maintenance and repair services & 0.7837 & 0.7400 & 0.7956 & 0.6801 & - & - \\
\hline Hotel and restaurant services & 1.0738 & 1.0632 & 0.7704 & 0.7014 & - & - \\
\hline Business services & 0.8680 & 0.8112 & 2.4883 & 2.2097 & - & - \\
\hline Commercial education & 0.8144 & 0.8221 & 0.5717 & 0.5511 & - & - \\
\hline Hospital-care activities & 0.9960 & 0.9828 & 0.5443 & 0.5317 & - & - \\
\hline Other health-care-related activities & 0.8197 & 0.8540 & 0.5513 & 0.5353 & - & - \\
\hline Private social services & 0.9467 & 0.8858 & 0.5356 & 0.5223 & - & - \\
\hline Other services & 0.8480 & 0.8188 & 0.8438 & 0.7459 & - & - \\
\hline Public education & 0.6919 & 0.6963 & 0.5375 & 0.5233 & - & - \\
\hline Public health & 0.8347 & 0.8441 & 0.5334 & 0.5205 & - & - \\
\hline Public administration and social security & 0.8268 & 0.8008 & 0.7167 & 0.6672 & - & - \\
\hline
\end{tabular}

Source: Prepared by the authors.

Note: Health sectors shaded. 


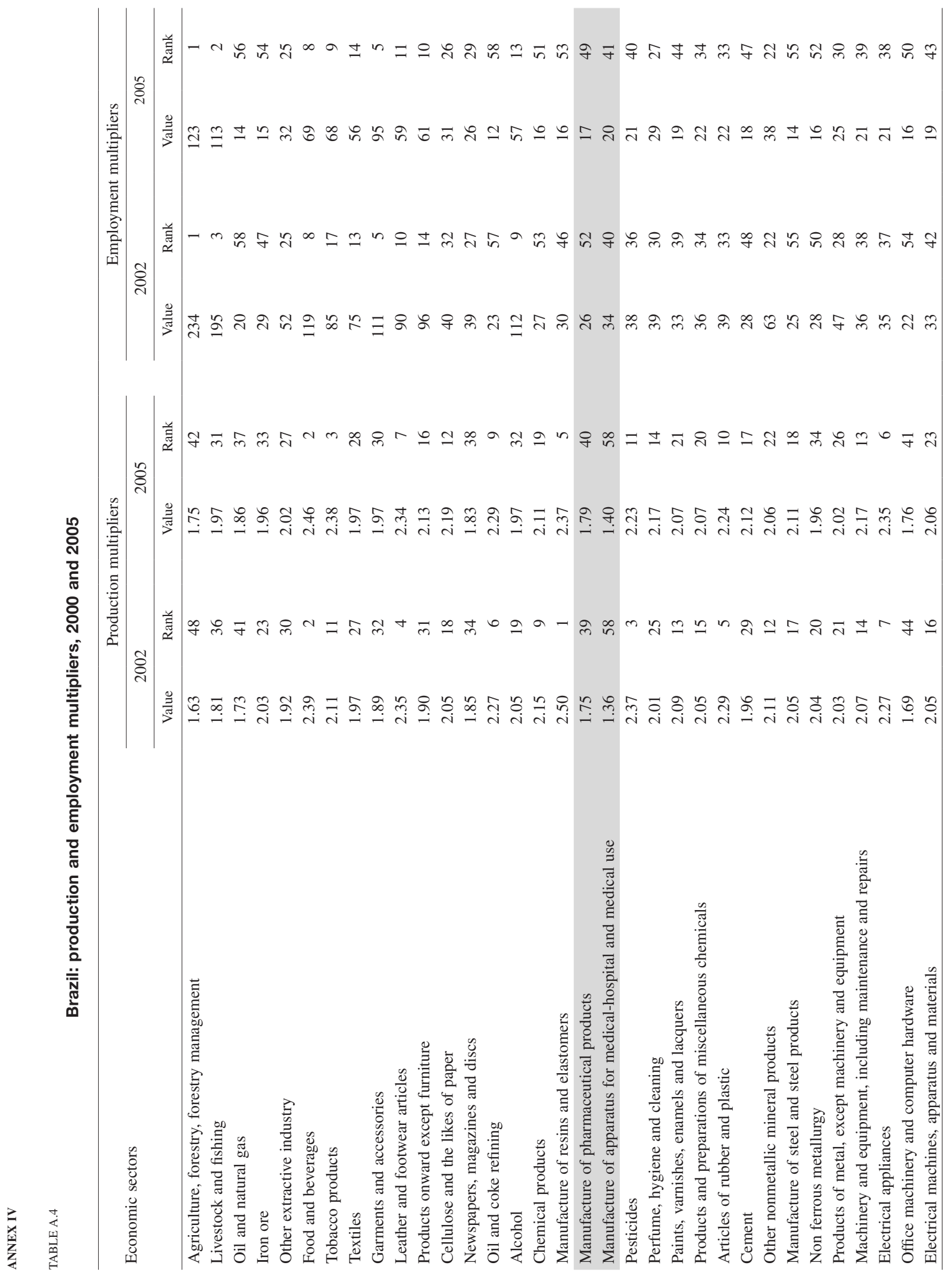




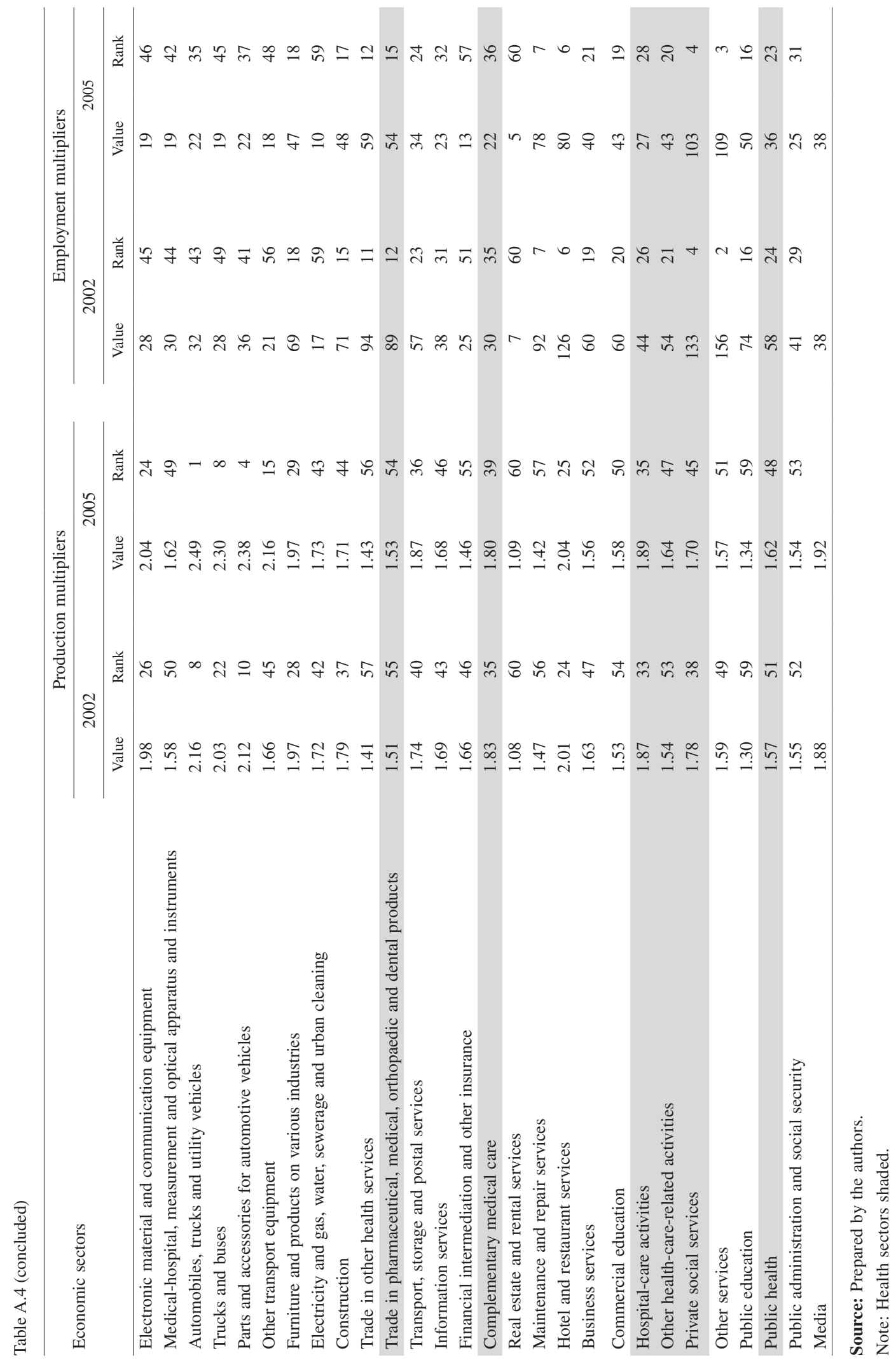




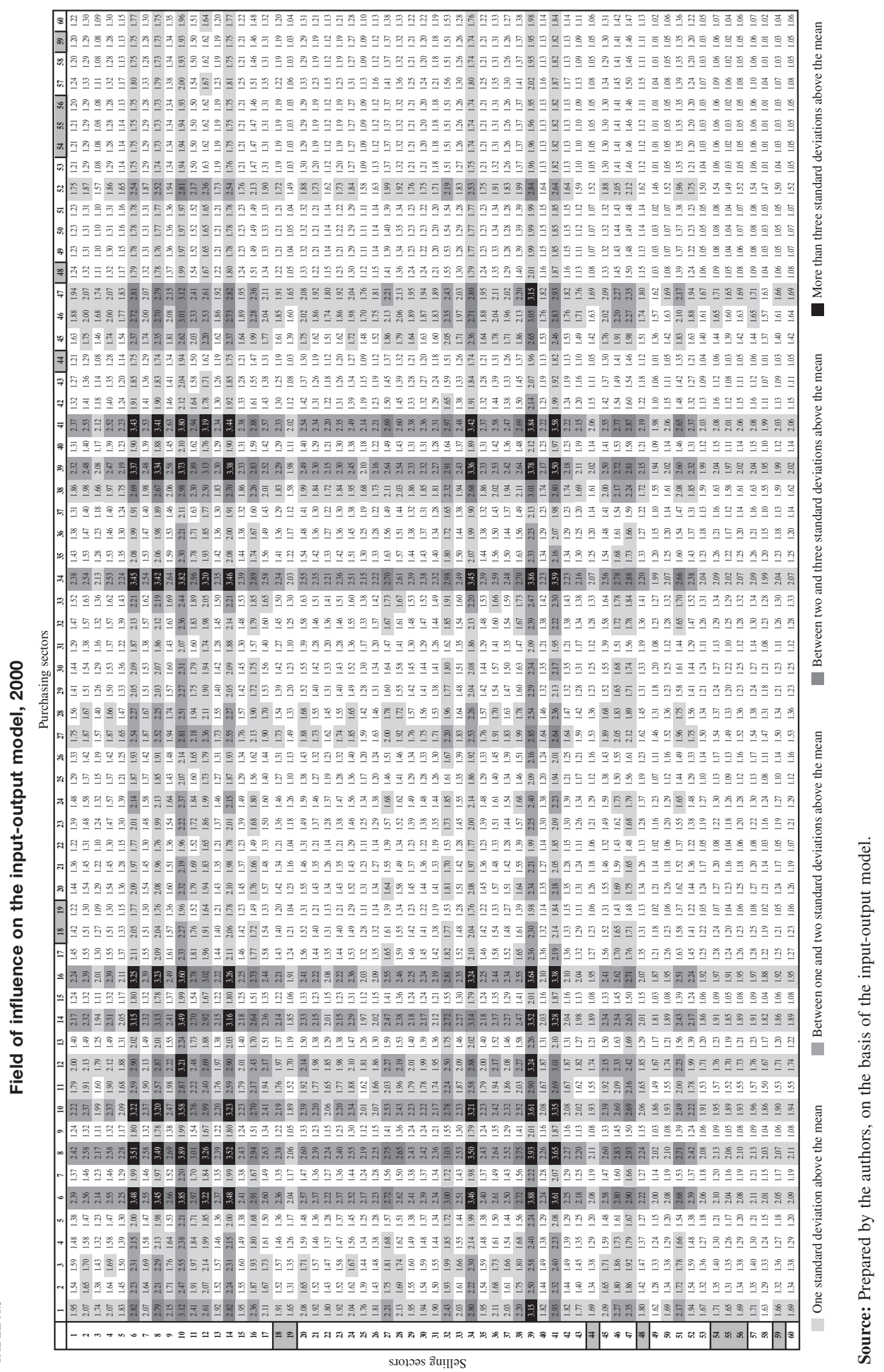

SYSTEMIC ANALYSIS OF THE HEALTH SECTOR THROUGH THE INPUT-OUTPUT MATRIX, 2000-2005 - FERNANDO SALGUEIRO PEROBELLI, MÔNICA VIEGAS ANDRADE, EDSON PAULO DOMINGUES, FLAVIANE SOUSA SANTIAGO, JOILSON DE ASSIS CABRAL AND LUCAS BARBOSA RODRIGUES 


\section{Bibliography}

Almeida, C. and others (2000), "Health sector reform in Brazil: A case study of inequity", International Journal of Health Services, vol. 30 , No. 1, sage.

Andrade, M.V. (2002), "A saúde na PNAD", Texto para Discussão, No. 170, Belo Horizonte, Federal University of Minas Gerais/ Centre for Regional Development and Planning.

Azzoni, C.R. and others (2007), "Social policies, personal and income inequality in Brazil: I-O analysis of the 'Bolsa Família' progam", Anais do V Encontro Nacional da Associação Brasileira de Estudos Regionais e Urbanos, Pernambuco.

Betarelli Junior, A.A., S.Q.A. Bastos and F.S. Perobelli (2008), "As pressões das exportações setoriais sobre os modais de transporte: uma abordagem híbrida e intersetorial de insumo-produto", Pesquisa e Planejamento Econômico, vol. 38, No. 3, Institute of Applied Economic Research (IPEA).

Bloom, D., D. Canning and J. Sevilla (2001), "The effect of health on economic growth: Theory and evidence", NBER Working Paper, No. 8587, Cambridge, Massachusetts, National Bureau of Economic Research.

Brazil, Ministry of Health (2010), Doenças infecciosas e parasitárias, Brasilia.

(2004), Saúde Brasil 2004: uma análise da situação de saúde, Brasilia.

Camargo, M.C.S., R.N. Rodrigues and C.J. Machado (2006), "Expectativa de vida saudável para idosos brasileiros, 1998 e 2003", Anais do XV Encontro Nacional de Estudos Populacionais, Caxambu, Minas Gerais.

Campelo, V., M.A.G. Gonçalves and E.A. Donadi (2005), "Mortalidade por doenças infecciosas e parasitárias no Município de Teresinapi (Brasil), 1971-2000”, Revista Brasileira de Epidemiologia, vol. 8, No. 1, Brazilian Association of Collective Health.

Correa, H. and B. Parker (2005), "An application of organizational input-output analysis to hospital management", Socio-Economic Planning Sciences, vol. 39, No. 4, Amsterdam, Elsevier.

Guilhoto, J.J.M. (2004), Análise de insumo-produto: teoria e fundamentos, São Paulo.

Guilhoto, J.J.M. and others (1994), "Índices de ligação e setores-chave na economia brasileira: 1959/80", Pesquisa e Planejamento Econômico, vol. 24, No. 4, Institute of Applied Economic Research (IPEA).

Hilgemberg, E.M. and J.M. Guilhoto (2006), "Uso de combustíveis e emissões de $\mathrm{CO}_{2}$ no Brasil: um modelo inter-regional de insumoproduto", Nova Economia, vol. 16, No. 1, Belo Horizonte.

Hirschman, A.O. (1958), The Strategy of Economic Development, New Haven, Yale University Press.

Hongyi, W. (2009), "The Analysis of Input-Output in Hospital and the Practical Application in Medicine Health Domain", document presented at the 17th International Conference on InputOutput Techniques.

IBGE (Brazilian Geographical and Statistical Institute) (2008), Economia da saúde: uma perspectiva macroeconômica 2000-2005, Rio de Janeiro.

(n/d), "Matriz de insumo-produto (2000 e 2005)" [online] http://www.ibge.gov.br/.

Imori, D. and J.J.M. Guilhoto (2007), "Estrutura produtiva brasileira e emissão de CO2", Anais do V Encontro da Associação Brasileira de Estudos Regionais e Urbanos, Recife.

Luna, E. (2002), "A emergência das doenças emergentes e as doenças infecciosas emergentes e reemergentes no Brasil", Revista Brasileira de Epidemiologia, vol. 5, No. 3, Brazilian Association of Collective Health.

Marinho, A., S.S. Cardoso and V.V. Almeida (2009), "Brasil e oCDE: avaliação da eficiência em sistemas de saúde", Texto para Discussão, No. 1370, Institute of Applied Economic Research (IPEA)
Mattos, R.S. and others (2008), "Integração de modelos econométricos e de insumo produto para previsões de longo prazo da demanda de energia no Brasil", Estudos Econômicos, vol. 38, São Paulo, University of São Paulo.

Miller, R. and P. Blair (2009), Input-Output Analysis: Foundations and Extensions, New Jersey, Prentice-Hall.

Moreira, G. (2007), "Politicas sociais, desigualdades pessoais e regionais da renda no Brasil: uma analise de insumo-produto", Luiz de Queiroz College of Agriculture.

OECD (Organization for Economic Cooperation and Development) (2010), "OECD Health Data 2010: Statistics and Indicators" [online] http://www.oecd.org.br.

Perobelli, F.S., R.S. Mattos and W.R. Faria (2007), "Interações energéticas entre o Estado de Minas Gerais e o restante do Brasil: uma análise inter-regional de insumo-produto", Economia Aplicada, vol. 11, No. 1, São Paulo, University of São Paulo.

Rasmussen, P.N. (1952), Studies in Inter-Sectoral Relations, Amsterdam, North-Holland.

Ribeiro, M.B. (2009), "Eficiência do gasto público na América Latina: uma análise comparativa a partir do modelo semi-paramétrico com estimativa em dois estágios", Gestión Pública series, No. 67 (LC/L.2883-P), Santiago, Economic Commission for Latin America and the Caribbean (ECLAC). United Nations publication, Sales No. P.08.II.G.28

(2008), "Desempenho e eficiência do gasto público: uma análise comparativa entre o Brasil e um conjunto de países da América Latina", Texto para Discussão, No. 1368, Brasilia, Institute of Applied Economic Research (IPEA).

Ribeiro, M.B. and W. Rodrigues Jr. (2006), "Eficiência do gasto público na América Latina", Boletim de Desenvolvimento Fiscal, No. 3 , Institute of Applied Economic Research (IPEA).

Robine, J.M., I. Romieu and E. Cambois (1999), "Health expectancy indicators", Bulletin of the World Health Organization, Geneva, World Health Organization (WHO).

Rodrigues, R.L. and J.J.M. Guilhoto (2004), "Estrutura produtiva, relações intersetoriais e cooperativas agropecuárias no Paraná em 1980 e 1985", Revista de Economia e Sociologia Rural, vol. 42, No. 2, Brazilian Society of Rural Sociology and Economics.

Schramm, J.N.A. and others (2004), "Transição epidemiológica e o estudo de carga de doença no Brasil", Ciência \& Saúde Coletiva, vol. 9, No. 4, Brazilian Association of Collective Health

Sesso Filho, U.A. and others (2006), "Interações sinérgicas e transbordamento do efeito multiplicador de produção das grandes regiões do Brasil", Economia Aplicada, vol. 10, No. 2, São Paulo, University of São Paulo.

Sonis, M. and G.J.D. Hewings (1992), "Coefficient changes in inputoutput models: theory and applications", Economic Systems Research, vol. 4, No. 2.

Terra, L.P. and B.L. Queiroz (2010), "Qualidade de vida: qual é a esperança de vida feliz no Brasil?", Anais do XVII Encontro Nacional de Estudos Populacionais, Caxambu, Minas Gerais.

Toyoshima, S. and M.J. Ferreira (2002), "Encadeamentos do setor de transportes na economia brasileira", Planejamento e Políticas Públicas, No. 25, Institute of Applied Economic Research (IPEA).

World Bank (2007), "PIB per cápita" [online] http://datos.bancomundial. org/indicador/NY.GDP.PCAP.CD.

wHo (World Health Organization) (2010), "Global health indicators", World Health Statistics 2010, Geneva [online] http://www.who.int/ gho/publications/world_health_statistics/EN_WHS10_Full.pdf. (2009), World Health Statistics 2009, Geneva [online] http://www.who.int/gho/publications/world_health_statistics/ EN_WHS09_Full.pdf.

(2001), Macroeconomics and Health: Investing in Health for Economic Development. Report of the Commission on Macroeconomics and Health, Geneva. 